\title{
SUMMARY
}

Raikovska Halyna, ShostadhukAndrii. Tasks of geometric modeling mechanisms in professional training of undergraduates in Mechanics.

The research covers the issues of the geometric modeling role for solving the tasks of synthesis and analysis of mechanisms in the process of professional training of undergraduates in Mechanics.

The purpose of the article is to explore formation of professional competence in future specialists in the field of robots. Research methods: theoretical, empirical.

Modern tempos of occurring new and modern available machinery demand from a mechanical engineer fulfilling responsible projects and calculations of the corresponding quality in the maximum brief terms.

Presently available software products enable to carry out such research in 3D space. Subsequently, whilst training undergraduates in Mechanics it is necessary to provide the educational process with the opportunity of solving topical tasks in studying the mechanisms of modern technological and transport machines, using corresponding software products. Scientific methods of analysis and description were used for separating requirements to the educational subject "Theory of machines and mechanisms" at the contemporary stage.

Classification of tasks for geometric modeling was offered according to which all the tasks may be divided into three groups: designing (synthesis) new mechanisms, researching kinematic and power properties on purpose to increase productivity of the technological process and products quality. It was introduced the brief content of each task. It was given input and output parameters which are given according to the task set involving geometric modeling and results of its solution.

It was noted that the advantages of using 3D models of the mechanism for solving both educational and production tasks are the following ones: evidence, appropriateness of size and geometric form of a real mechanism and its model, ability for kinematic and power analysis and obtaining correct results. It is shown the necessity of applying geometric models for studying the topics that are not considered in the traditional course concerning the theory of machines and mechanisms. Such topics may refer to: fluctuation processes, friction and wear processes, accuracy of mechanisms.

The prospect of further research is continuation of implementation of geometric modeling in professional training of future M echanics.

Key words: mechanism, geometric modeling, analysis, synthesis, kinematics, accuracy, fluctuation, optimization, friction and wear, engineering creativity.

УДк [378.22:80]:316.61

Олена Салі

Ізмаїльський державний гуманітарний університет

ORCID ID 0000-0003-4818-5895

DOI 10.24139/2312-5993/2019.08/296-308

\section{СОЦІОКУЛЬТУРНИЙ ПІДХІД У ПІДГОТОВЦІ МАЙБУТНІХ УЧИТЕЛІВ- ФІлологів}

У статті проаналізовано соціокультурний підхід у викладанні англійської мови студентам як ванливий чинник підготовки майбутніх фрілологів; розкриваються поняття «соціокультурна компетентність» $i$ «діалог культур»; наводяться приклади 
практичного використання зазначеного підходу в роботі зі студентами ІДГУ. Визначено основні характерні особливості соціокультурної компетентності, які складають чілісний механізм у вивченні іноземних мов. Автор досліджує основні напрями формування та вдосконалення у студентів соціокультурної компетентності через упровадження інтерактивних технологій. Проаналізовано феномен «аудіолінгвальний метод». На прикладі студентів Ізмаїльського державного гуманітарного університету доведено ефрективність соціокультурного розвитку. Автор акцентує увагу на тому, що навчання іноземної мови студентів полягає у формуванні в них комунікативних умінь усного та писемного мовлення у професійній сфрері. Володіння соціокультурними засобами спілкування є запорукою успішної професійно орієнтованої комунікації із зарубіжними партнерами та колегами.

Ключові слова: сочіокультурний підхід, сочіокультурна компетентність, професійно орієнтоване іншомовне спілкування, сочіокультурні засоби спілкування, аудіолінгвальний метод, діалог культур, іншомовна освіта, країнознавча інформація.

Постановка проблеми. На сучасному етапі розвитку нашого суспільства значимість вивчення іноземної мови зростає, загострюється потреба в оволодінні іноземною мовою як засобом спілкування. Мова відображає особливості життя людей. Вивчаючи різноманіття планів вираження, можна багато чого зрозуміти й дізнатися про культуру різних країн мови, що вивчається. А це підводить нас до необхідності формування соціокультурної компетенції. Соціокультурна компетенція $€$ комплексом знань про цінності, вірування, поведінкові зразки, звичаї, традиції, мову, досягнення культури, властивих певному суспільству, що характеризують його, формують у студентів повагу до інших культур і народів в умовах міжкультурної комунікації. Соціокультурна компетенція передбачає ціннісні відносини, які реалізуються в діях, поведінкових зразках і діяльності. Навчання іноземним мовам із використанням соціокультурного підходу допомагає нам відкрити «лик», особистість у «чужому», наближає «чуже», у той самий час виникає новий погляд на «своє». Саме з таким підходом формуються вміння в пізнанні власної культури й культури інших народів, адже чуже має бути пізнано і відкрито в своєму власному, у своїй власній культурі, тобто пізнання «чужої» культури може здійснюватися тільки через свою власну.

Сучасна система іншомовної освіти в закладах вищої освіти повинна відповідати вимогам полікультурної світової спільноти, що розвивається під впливом глобалізації та інтеграції. Названі соціальні процеси привели до того, що англійська мова $є$ мовою глобального спілкування, а навчання іноземної мови студентів 3ВО спрямоване на підготовку майбутніх фахівців до іншомовного спілкування в професійній сфері.

Науково обґрунтовано, що при досягненні взаєморозуміння в процесі іншомовного спілкування комуніканти повинні подолати не тільки мовний, а й культурний бар'єри (Тер-Мінасова, 2008, с. 28), тому іншомовне спілкування являє собою міжкультурну комунікацію. У даний час сформувалося соціальне замовлення на конкурентоспроможного 
фахівця, що володіє професійними й загальнокультурними компетенціями і здатного успішно вирішувати практичні завдання, що виникають в умовах сучасного професійного співтовариства. Розширення міжнародного співробітництва, участь фахівців у міжнародних конференціях, проходження закордонних стажувань, а також подальше навчання випускників бакалаврату в магістратурі, аспірантурі і в зарубіжних 3ВО вимагають активного володіння іноземною мовою на високому рівні.

Аналіз актуальних досліджень. Роль соціокультурної компетентності у вивченні іноземних мов аналізується в дослідженнях М. Байрама, Р.Мильруд, Г.Нойнера, П. Сисоєва. Питаннями формування бази соціокультурної компетентності у студентів досліджувалися такими авторами, як Е. Астафурова, Н. Ішханян, М. Богатирьова, Е. Еліна. Науковці Г. Воробйов і Є. Воробйова розглядали особливості формування соціокультурної компетентності майбутніх учителів іноземних мов. Окрім цього, зазначена компетентність висвітлюється й крізь призму післядипломної освіти (В. Сафонова, Е. Кавнатська, Е. Смирнова, Л. Кузьміна).

Аналіз вивченої літератури з даного питання показав, що багато авторів розглядають соціокультурну компетентність із позиції «взаємовивчення» культури і мови тієї чи іншої країни.

Формування цілей статі (постановка завдання): 1) уточнити сутність поняття «соціокультурний підхід»; 2) розкрити сутність досвіду соціокультурної компетентності; 3) визначити основні компоненти соціокультурної компетентності та її роль у вивченні іноземних мов.

Методи дослідження. Обираючи методи для визначення ефективності проектів для формування іншомовної інтерактивної компетентності студентів, ми, у першу чергу, оцінювали ступінь їхньої необхідності та об'єктивності. Тому для досягнення поставленої мети нами був використаний комплекс теоретичних та практичних методів дослідження: аналіз наукової та науководослідної літератури - з метою з'ясування стану висвітлення досліджуваного феномену; педагогічне спостереження, аналіз та систематизація результатів навчальної діяльності студентів, формулювання висновків і визначення напрямів подальших наукових розвідок.

Виклад основного матеріалу дослідження. Специфіка курсу іноземної мови полягає в поєднанні професійно-ділового та соціокультурного аспектів - двох взаємопов'язаних складових міжкультурної комунікації майбутніх фахівців-філологів.

Соціокультурний аспект підготовки фахівців до іншомовного спілкування спрямований на навчання соціокультурних засобів спілкування й відображає соціокультурний підхід до викладання іноземних мов. Даний підхід полягає в навчанні іншомовного спілкування в контексті діалогу культур на основі зіставлення і усвідомлення студентами лінгвокультурних особливостей своєї та зарубіжної країн (Сафонова, 2001, с. 20). Діалог 
культур визначається як «взаємодія культур у процесі вивчення мови, що забезпечує адекватне взаєморозуміння і взаємозбагачення представників різних лінгвокультурних спільнот» (Библер,1989, с. 5).

Результатом соціокультурного підходу $\epsilon$ соціокультурна компетентність, що входить до складу комунікативної компетенції. Традиційно соціокультурна компетенція визначається як «сукупність знань про країну, мова якої вивчається, національно-культурні особливості соціальної і мовної поведінки носіїв мови та здатність користуватися такими знаннями в процесі спілкування, дотримуючись звичаїв, правил поведінки, норм етикету, соціальних умов і стереотипів поведінки носіїв» (Гальскова, 2004, с. 35). Сформованість цієї здатності вказує не тільки на готовність до міжкультурного спілкування, а й на володіння соціокультурними знаннями про певну іноземну країну, способи вживання мовних засобів спілкування в різних ситуаціях взаємодії.

У зміст навчання іноземної мови в межах соціокультурного підходу входять такі компоненти:

1) лінгвістичний;

2) країнознавчий;

3) прагматичний (правила мовної й соціальної поведінки, прийняті в країні мови, що вивчається, у різних ситуаціях спілкування, у тому числі професійних);

4) етичний (вивчення моральних цінностей, менталітету носіїв мови).

Процес формування соціокультурної компетентності студентів здійснюється з урахуванням напряму профільної підготовки майбутніх філологів. На заняттях проводиться поглиблене вивчення соціокультурних засобів професійно орієнтованого спілкування за тематичним принципом, зафіксованим у нормативних документах 3ВО.

Наприклад, студенти Ізмаїльського державного гуманітарного університету отримують базові соціокультурні знання на заняттях із англійської мови в процесі вивчення тем, передбачених робочими програмами дисципліни «ноземна мова». Соціокультурна тематика занять охоплює такі теми: сімейні традиції, устрій життя, дозвілля і розваги в сім'ї, вища освіта в Україні і за кордоном, студентське життя в Україні і за кордоном, студентські міжнародні контакти: наукові, професійні, культурні; мова як засіб міжнародного спілкування, спосіб життя сучасної людини в Україні і за кордоном. У процесі вивчення тем професійної сфери також відбувається формування соціокультурної компетентності, орієнтованої на професійне іншомовне спілкування майбутніх фахівців-філологів.

У процесі здійснення соціокультурної підготовки студентів важливо враховувати ціннісний аспект, тому крім ознайомлення із соціокультурним портретом країни, мова якої вивчається, на заняттях необхідно обговорювати такі питання сучасного полікультурного світу, як проблеми расизму, 
дискримінації, екологічні та демографічні проблеми, конфлікти й можливі ненасильницькі шляхи їх вирішення (Орехова, 2004 с. 28). Формування соціокультурної компетентності студентів здійснюється на основі автентичних матеріалів, що містять культурокраїнознавчу інформацію (художня і науковопопулярна література, аудіо- та відеоматеріали). Як відомо, кількість аудиторних годин дуже обмежена, тому застосовується практика поєднання аудиторної та самостійної позааудиторної форм роботи студентів: організація та проведення студентських конференцій, проектне навчання, гурткова робота. Теми занять та доповідей визначаються спільно викладачем і студентами, що сприяє підвищенню мотивації студентів. Далі студенти підбирають матеріал за темою в різноманітних джерелах інформації. Вікова група студентства відрізняється підвищеним інтересом до інтернет-ресурсів, комп'ютерних програм, які дозволяють інформативно й ілюстративно виконати завдання. Результатом такого виду самостійної роботи є доповідь, проект або презентація. Як показує досвід, такі творчі завдання сприяють підвищенню пізнавальної активності студентів та створення позитивної мотивації до вивчення англійської мови.

Реалізація соціокультурного підходу в навчанні іноземних мов у школі сприяє формуванню в учнів, в умовах іншомовного навчального спілкування, таких необхідних якостей, як:

- культурна неупередженість, толерантність і соціокультурна спостережливість;

- готовність до спілкування та співпраці з людьми в іншомовному середовищі;

- мовний і соціокультурний такт і ввічливість;

Формування та вдосконалення у студентів соціокультурної компетентності спрямовані на:

- розвиток здатності орієнтуватися в соціокультурних аспектах життєдіяльності людей в країнах, мова яких вивчається;

- формування навичок та вмінь шукати способи виходу із ситуацій комунікативного збою через соціокультурні перешкоди при спілкуванні;

- формування поведінкової адаптації до спілкування в іншомовному середовищі, розуміння необхідності слідувати традиційним канонам ввічливості в різних країнах;

- оволодіння способами подання рідної культури в іншомовному середовищі.

Соціокультурний підхід забезпечує засвоєння мови в тісному зв'язку з іншомовною культурою, тому поряд із комунікативним, особистіснодіяльнісним підходами слід використовувати і соціокультурний підхід. Інтегруючи дані підходи в навчанні можна досягти високих результатів. Уміння ефективно користуватися в комунікації соціокультурними мовними знаннями означає, що той, хто говорить іноземною мовою, має соціокуль- 
турну компетенцію. Соціокультурна мовна компетентність - це є соціокультурні мовні знання, які адекватно використовуються в міжкультурній комунікації. Відсутність навичок соціокультурної компетентності значно ускладнює комунікацію. Багатьма визнається сьогодні, що головною причиною нерозуміння при міжкультурному спілкуванні $€$ відмінність національних свідомостей комунікантів, а не відмінність мов (Сафонова, 1998, с. 8).

Соціокультурна компетентність забезпечує адекватність спілкування 3 носіями мови і має на увазі певний рівень володіння країнознавчими фоновими знаннями (тобто знаннями, якими володіють представники даної етнічної і мовної спільноти) і найбільш вживаними мовними одиницями 3 національно-культурної семантикою. Незнання соціокультурного контексту, у якому функціонує англійська мова, веде до інтерференції культур і ускладнює процес спілкування (Селіванова, 2007, с. 67).

За концепцією Ради Європи, соціокультурний підхід припускає необхідність формування ціннісного і на його основі відповідального ставлення людини до навколишнього світу як основи для «входження» в культуру; організацію такого освітнього процесу і створення такого освітнього середовища, щоб формування особистості відбувалося в контексті загальнолюдської культури з урахуванням конкретних культурних умов життєдіяльності людини; визначення змісту освіти на рівні змісту сучасної світової культури; організацію взаємодії дитини зі світом культури: на всіх рівнях (мікро-, мезо-, макро-); у межах всіх вікових субкультур (однолітки, старші, молодші).

Соціокультурний підхід спирається на теорію цінностей (аксіологія) і зумовлений об'єктивним зв'язком людини з культурою як системою цих цінностей. На передній план виступає ідея розвитку дитини через присвоєння загальнокультурних цінностей, розуміння нею природи й людини як найбільшої цінності, бажання жити в гармонії з навколишнім світом у відповідності з його законами.

Соціокультурний підхід розвивається з другої половини 80-х років. Соціокультурний концепт дидактики і методики навчання іноземної мови більшою мірою, ніж прагматико-функціональний концепт, ґрунтується на педагогічних ідеях, що випливають із точного аналізу перспективи учня, досліджень факторів його життєвого досвіду, навчальних традицій і звичок, знання світу, співвідношення вихідної і цільової культур, індивідуальної мотивації й успіхів у навчанні, інституційних умов (часу проведення занять, статусу іншомовних предметів, оснащеності технічними засобами, кваліфікації викладачів). Він розвивається переважно там, де виявляється яскраво виражена географічна і культурно-територіальна дистанція, й інші суспільні відносини в порівнянні з країнами, мова яких вивчається. Соціокультурний підхід у навчанні виходить із того, що висловлювання повинні бути здійснені і зрозумілі на тлі іншої культури. Знайомство студентів із різними формами прояву чужої культури означає не тільки передачу 
чужого світу як об'єктивованого предмета навчання, а й передбачає зробити більш зрозумілим власний світ через зворотній зв'язок, а також зворотній вплив на власний досвід і процеси соціалізації. Таким чином, студенти стають більш сприйнятливими до поведінки і до реакції людей іншого культурного простору, що сприяє розвиткові емпатії. Це створює можливість вступу в соціальну взаємодію з представниками інших культур, подолання нерішучості перед обличчям нового, іншого культурного оточення.

На думку В. Пауелса, контрастно сплановане країнознавство таїло небезпеку зміни ролей та ідентичності, оскільки воно було спрямовано майже виключно на відмінності країни, мова якої вивчається. У той самий час соціокультурне навчання або соціокультурна комунікація включають у себе зворотній вплив на власну позицію стосовно культурного оточення своєї країни і його оцінку. Вони означають, таким чином, критичну рефлексію власних громадських норм і уявлень про норми і принципи дії власної мовної поведінки. Оскільки соціокультурне навчання випливає не просто із зіткнення різних культур і їх носіїв, воно включає, з одного боку визначення особливостей, а з іншого боку - нове обґрунтування або критичне осмислення власних норм для успішного здійснення міжкультурного діалогу. Сюди відносяться тексти, які пояснюють обумовлене культурою нерозуміння й розкривають зворотній вплив на власну поведінку.

Соціокультурний підхід, який отримав обґрунтування в роботах В. Сафонової, проголошує в якості основоположного принципу «взаємозалежний комунікативний і соціокультурний розвиток особистості, яка вивчає іноземну мову засобами цієї мови» (Сафонова, 2001, с. 20).

Як історичний екскурс відзначимо, що вже в надрах аудіолінгвального методу Ч. Фріза і Р. Ладо (середина XX ст.) зверталася увага на доцільність ураховувати особливості національного менталітету, культури, які проявляються в мовній поведінці людей. У сучасних дослідженнях, спрямованих на визначення змісту соціокультурного підходу в навчанні мовам, запропоновано три напрями його реалізації (П. Сисоєв): засіб соціокомунікаціі, національна ментальність і національне надбання.

Соціокомунікація трактується як сукупність прийомів і засобів усної та письмової передачі інформації представниками визначеної культури або субкультури. До них слід віднести такі: мова, у якій включені специфічні відмінності між існуючими мовними варіантами; паралінгвістичні навички, наприклад жести, інші знаки невербального спілкування; особливості письмової комунікації - нормативні вимоги оформлення дат, звернень, адрес, складання резюме, ділових листів, звітів. Національна ментальність сприймається як спосіб мислення представників певної культури або субкультури, який визначає їхню поведінку й очікування подібної поведінки з боку інших. У контексті мовної освіти пропонується розглядати ментальність народу країни, мова якої вивчається, у трьох вимірах: 
загальному, ситуативному й культурному самовизначенні. Національне надбання розглядається як соціокультурний компонент змісту навчання іноземної мови, який може бути представлений, на думку П. Сисоєва, такими культурними напрямами, як наука і мистецтво, історія і релігія, національні парки, історичні заповідники та інші місця туристичного паломництва. Методичний ракурс сприйняття «національного надбання» формує своєрідний фон національних соціокультурних знань-концептів, який представляє культурну цінність (Сисоєв, 2004, с. 15).

Взявши свій початок в аудіолінгвальному методі, соціокультурний підхід розвивався на базі комунікативного методу із залученням країнознавчих матеріалів, створюючи соціокультурний фон, контекст іншомовного спілкування. Логічно доповнюючи й удосконалюючи комунікативний підхід, соціокультурний підхід орієнтує комунікантів на зіставлення картин світу в контексті національної та світової цивілізацій і тим самим підводить студента до рефлексії власних цінностей, до усвідомлення національного надбання своєї країни, свого народу (Хуторский, 2002).

Студенти ІДГУ аби більш детально пізнати країну, мову якої вони вивчають, працювали з такими вправами:

Вправа 11 (after-reading task)

After-reading task: Say if my sentences are true or false.

- Every month there is a big Christmas tree in Trafalgar Square (true).

- People from Norway decorate the Christmas tree for Londoners (false).

- There are many people in the shops on Christmas Eve (true).

- The shops are busy at Christmas (true).

- People don't buy presents for their family and friends (false).

- The English open their presents on Christmas Eve (false).

- For Christmas lunch people eat pizza and hamburgers (false).

- The 26th of December is Boxing Day (true).

Соціокультурний розвиток студентів сприяє:

- розумінню взаємозв'язку між зразками поведінки, які склалися, традиціями, цінностями, відносинами, властивими культурі мови, що вивчається;

- розумінню взаємозв'язку між ідеологією і продуктами матеріальної і духовної культури країни мови, що вивчається;

- усвідомленню ролі рідної мови й культури в розвиткові загальнолюдської культури;

- формуванню аналітичного підходу до вивчення зарубіжної культури в зіставленні із культурою своєї країни;

- розвитку в студентів мовної культури опису реалій країни, що вивчається, і реалій українського життя іноземною мовою;

- формуванню оціночно-емоційного ставлення до світу. 
Оволодіння мовним оформленням даної стратегії з відповідними їй соціокультурними тактиками в ході створення певних методичних умов сприяє формуванню вмінь підтримки комунікативного контакту з носієм англійської мови.

При розробці методики формування соціокультурної компетентності Т. Астафурова логічно спирається на трактування спілкування в аспекті міжкультурної взаємодії як «складного багатопланового процесу встановлення і розвитку контактів між представниками різних культур, що породжується потребами спільної діяльності і включає в себе обмін інформацією, вироблення єдиної стратегії взаємодії, сприйняття і розуміння іншої людини» (Астафурова, 1997, с. 27).

Аналіз компетентнісного фактору нами здійснено на підставі двох положень: по-перше, саме компетентність визначає успішність оволодіння іноземною мовою; по-друге, компетентнісний фактор повинен розглядатися в тісному взаємозв'язку із культурно-історичним характером сучасної парадигми освіти в цілому. У результаті ми дійшли до висновку про наявність зростаючої ролі соціокультурного підходу в мовній освіті взагалі та зростаючого значення лінгвосоціокультурного компонента іншомовної комунікативної компетентності.

Необхідність використовувати соціокультурний підхід як найважливіший базис у навчанні іноземних мов зумовлена прагненням забезпечити якість сучасної освіти на основі збереження його фундаментальності та відповідності актуальним, а також перспективним потребам особистості, суспільства. Професійна мобільність, комунікабельність, толерантність $€$ найважливішими якостями конкурентоспроможності фахівця будь-якої сфери діяльності. Досягнення цих якостей $є$ можливим за умови вдосконалення системи перепідготовки й підвищення кваліфікації кадрів, їх програми вже не можливо уявити без «мовної складової». Відкритість суспільства висуває вказану проблему на новий рівень - міжнародну, професійну, академічну мобільність, що вимагає також формування сучасного мислення. Рішення будь-яких проблем на цьому рівні ускладнюється поза контекстом діалогу культур, тому такі поняття, як суспільство і його культура, формують основу сучасної освітньої-котельної політики будь-якої держави.

Сутність соціокультурного підходу полягає в тому, що якими б мотивами людина не керувалася в своїй діяльності, у термінах якої 6 науки ці мотиви не описувалися, все це фіксується в культурі. Слід зазначити, що даний підхід не заперечує економічний, психологічний та інші фактори розвитку суспільства, системи освіти, але пріоритетним є аналіз культури, саме він приймається як програма діяльності, у тому числі з організації мовної освіти. У методиці викладання іноземних мов соціокультурний підхід розвивається на базі комунікативного підходу. 
Соціокультурна компетентність включає певні вміння, які стають об'єктом педагогічної діяльності в межах мовної освіти. Зазначимо деякі з них, які є пріоритетними при організації навчального процесу, професійної підготовки майбутніх викладачів іноземної мови:

•уміння співвідносити менталітет рідної і англомовної культури, яка вже характеризується як «бікультурна» в силу наявності двох варіантів англійської мови: американського і британського;

•уміння гнучко використовувати стратегії англомовної комунікативної поведінки для встановлення й підтримки контакту 3 представниками англомовних країн;

•уміння виступати в ролі посередника між представниками своєї та іншомовної культури; здатність ефективно усувати непорозуміння, уникати і нейтралізувати конфліктні ситуації, викликані міжкультурними відмінностями;

-уміння долати стереотипи, що склалися;

-уміння користуватися мовними засобами як соціокультурними маркерами, що характеризують партнера по спілкуванню, що створюють його портрет;

-уміння адаптувати свою промову до певної ситуації і здійснювати комунікативний намір.

Висновки та перспективи подальших наукових розвідок. Таким чином, соціокультурний підхід до іншомовної освіти студентів ІДГУ дозволяє вирішити такі завдання:

- розширення уявлення про культуру країни, мова якої вивчається;

- зіставлення рідної культури і культури інших народів;

- більш глибоке розуміння рідної культури та розвиток культурної ідентичності;

- етичне й естетичне виховання майбутніх філологів.

Практика роботи зі студентами показує, що особливий інтерес у студентів викликають такі теми, як форми дозвілля у Великій Британії і США, система освіти і життя студентів за кордоном, особливо мовного етикету в професійній діяльності зарубіжних колег.

Отже, сучасний стан мовної освіти постійно висуває нові завдання перед усіма суб'єктами освітнього процесу: нові вимоги орієнтовані на компетентнісний фактор підготовки майбутніх студентів-філологів. Разом із тим, це вимагає більш високого рівня професійної готовності викладачів, спонукає знову звертатися до здавалося 6 уже відомих і науково обґрунтованих позицій, оскільки виникають певні явища освітньої практики, що зумовлюють рішення зовсім інших завдань у зв'язку зі зростанням ролі соціокультурного підходу в контексті сучасної парадигми мовної освіти.

У результаті оволодіння соціокультурними засобами іншомовного спілкування студенти здатні помічати мовні кліше, характерні для певних 
ситуацій спілкування, вибирати мовні засоби спілкування відповідно до норм мови й етикету, підлаштовуватися під стиль спілкування іншомовного партнера. Окреслені здатності дозволяють випускнику ЗВО грамотно й дипломатично вибудовувати спілкування із зарубіжними партнерами або колегами в межах діалогу культур, досягаючи взаєморозуміння.

Перспективи подальшого дослідження ми пов'язуємо з вивченням особливостей системи формування соціокультурної компетентності майбутніх учителів-філологів у професійній діяльності в закладах освіти через сучасні інтерактивні технології.

\section{ЛITЕРАТУРА}

Астафурова, Т. Н. (1997). Стратегии коммуникативного поведения в профрессионально-значимых ситуациях межкультурного общения (автореф. дис. ... док. пед. наук). Москва (Astafurova, Т. N. (1997). Strategies for communicative behavior in professionally significant situations of intercultural communication (DSc thesis abstract). Moscow).

Библер, В. С. (1989). Культура. Диалог культур: опыт определения. Вопросы философиии, 6, 5 (Bibler, V. S. (1989). Culture. The dialogue of cultures: the experience of definition. Questions of philosophy, 6, 5).

Богатырева, М. А. (1998). Социокультурный компонент содержания профрессиональноориентированного учебника (автореферат. дис. ... канд. наук). М. (Bogatyreva, M. A. (1998). Sociocultural component of the contents of a professional-oriented textbook (PhD thesis abstract) M.).

Гальскова, Н. Д. (2004). Межкультурное обучение: проблема целей и содержания, обучения иностранным языкам. Иностранные языки в школе, 1, 35 (Halskova, N. D. (2004). Intercultural Learning: Problem of Goals and Content, Learning to Foreign Languages. Foreign Languages at School, 1, 35).

Мильруд, Р. П., Максимова, И. Р. (2000). Современные концептуальные принципы коммуникативного обучения иностранному языку. Иностранные языки в школе, 4 , 9-16 (Milrud, R. P., Maksimova, I. R. (2000). Modern Conceptual Principles of Communicative Learning for a Foreign Language. Foreign Languages at School, 4, 9-16).

Никитенко, 3. Н., Осиянова, О. М. (1994). О содержании национально-культурного компонента в обучении английскому языку младших школьников. Иностранные языки в школе, 5, 4-7 (Nikitenko, Z. N., Osianova, O. M. (1994). On the content of the national-cultural component in teaching English to younger schoolchildren. Foreign languages at school, 5, 4-7).

Орехова, И. А. (2004). Формирование лингвокультурологической компетенции в процессе обучения иностранным языкам. Иностранные языки в школе, 5, 28-30 (Orekhova, I. A. (2004). Formation of linguocultural competence in the process of teaching foreign languages. Foreign languages at school, 5, 28-30).

Пассов, Е. И., Кузовлев, В. П., Коростелев, В. С. (1987). Цель обучения иностранному языку на современном этапе развития общества. Иностранные языки в школе, 6 (Passov, E. I., Kuzovlev, V. P., Korostelev, V. S. (1987). The purpose of teaching foreign language at the present stage of society development. Foreign languages at school, 6).

Сафонова, В. В. (1998). Проблемы социокультурного образования в языковой педагогике. Культуроведческие аспекты языкового образования. М.: Еврошкола, 27-35 (Safonova, V. V. (1998). Problems of Socio-Cultural Education in Language Pedagogy. Cultural Aspects of Language Education. M.: Euro School, 27-35). 
Сафонова, В. В. (2001). Культуроведение в системе современного языкового образования. Иностранные языки в школе, 3, 17-24 (Safonova, V. V. (2001). Cultural Studies in the System of M odern Language Education. Foreign Languages at School, 3, 17-24).

Селіванова, Н. А. (2007). Реалізація сучасних підходів і тенденцій у викладанні французської мови на основі навчально-методичного комплексу «Синій птах». Иностранные языки в школе, 64-68 (Selivanova, N. A. (2007). Implementation of modern approaches and trends in the teaching of French on the basis of the Blue Bird educational-methodical complex. Foreign languages at school, 64-68).

Сысоев, П. В. (2004). Культурное самоопределение обучающихся в условиях языкового поликультурного образования. Иностранные языки в школе, 4, 14-20 (Sysoiev, P. V. (2004). Cultural self-determination of students in the conditions of linguistic multicultural education. Foreign languages at school, 4, 14-20).

Сисоєв, П. В. (2004). Концепция языкового поликультурного образования (культуроведение США) (автореф. дисс. ... докт. пед. наук). Москва (Sysoiev, P. V. (2004). The Concept of Language Multicultural Education (US Cultural Studies) (DSC thesis abstract). M oscow).

Тер-Минасова, С. (2008). Язык и межкультурная коммуникация. М.: Слово (TerM inasova, S. (2008). Language and Intercultural Communication. M .: Slovo).

Хуторской, А. В. (2002). Ключевые компетенции и образовательные стандарты. Интернет-журнал «Эйдос», 23 апреля. Режим доступа: http://eidos.ru/journal/2002/0423.htm (Hutorskoi, A. V. (2002). Key Competences and Educational Standards. Eidos Internet Magazine, April 23. Retrieved from: http:// eidos.ru/journal/2002/0423.htm).

Knyazyan, M., M ushynska, N. (2019). The formation of translator's research competence at the universities of Ukraine. The Journal of Teaching English for Specific and Academic Purposes, Vol. 7, No 1, 85-94.

Knyazyan, M., Mushynska, N. (2019). Social innovations in the professional training of managers under the conditions of knowledge economy development. Baltic Journal of Economic Studies, Vol. 5, No. 2, 137-143.

Sheils, (1993). Communication in the Modern Language Classroom. Strasbourg: Council of Europe Press, 1-2.

\section{PEЗЮME}

Сали Елена. Социокультурный подход в подготовке будущих учителейфилологов.

В статье проанализирован социокультурный подход в преподавании английского языка студентам как важный фактор подготовки будущих филологов; раскрываются понятия «сочиокультурная компетентность» и «диалог культур»; приводятся примеры практического использования указанного подхода в работе со студентами ИГгу. Определены основные характерные особенности социокультурной компетентности, которые составляют целостный механизм в изучении иностранных языков. Автор исследует основные направления формирования и совершенствования у студентов социокультурной компетентности путем внедрения интерактивных технологий. Проанализирован феномен «аудиолингвальный метод». На примере студентов Измаильского государственного гуманитарного университета доказана эфрфективность социокультурного развития. Автор акцентирует внимание на том, что обучение иностранному языку студентов заключается в формировании у них коммуникативных умений устной и письменной речи в профрессиональной срере. Знание 
социокультурных средств общения является залогом успешной профессионально ориентированной коммуникации с зарубежными партнерами и коллегами.

Ключевые слова: социокультурный подход, социокультурная компетентность, профессионально ориентированное иноязычное общение, социокультурные средства общения, аудиолингвальный метод, диалог культур, иноязычная образование, страноведческая информация.

\section{SUMMARY}

Sali Olena. Socio-cultural approach to training of the future teachers-philologists.

The article analyzes the socio-cultural approach in teaching English to students as an important factor in the preparation of future philologists; the concepts of "socio-cultural competence" and "dialogue of cultures" are revealed; examples of practical use of this approach in work with students of the ISHU are given. The main characteristic features of socio-cultural competence, which constitute the integral mechanism in the study of foreign languages, are determined. The author investigates the main directions of formation and improvement of students of socio-cultural competence through introduction of interactive technologies. The phenomenon of "audio-lingual method" is analyzed. An example of the students of the Izmail State Humanitarian University proved the effectiveness of sociocultural development. The author focuses on the fact that teaching of a foreign language of students is in the formation of their communicative skills of oral and written speech in the professional field. Possession of socio-cultural means of communication is the key to a successful professional-oriented communication with foreign partners and colleagues.

As the author has noted, formation of sociocultural competence of students is carried out on the basis of authentic materials containing cultural information (fiction and popular science literature, audio and video materials). It is determined that the socio-cultural approach ensures acquisition of language in close connection with the foreign language culture, so along with the communicative, personal-activity approaches should be used the socio-cultural approach. By integrating these approaches in learning you can achieve high results. The essence of sociocultural approach is analyzed. It can be concluded that, as a result of mastering the sociocultural means of foreign language communication, students are able to notice the language clichés characteristic of certain situations of communication, choose language means of communication in accordance with the norms of language and etiquette, adjust to the style of communication of a foreign language partner. Knowledge of sociocultural competence will allow students to find their place in the international arena and to be a full participant in international communication. That's why the need to use the sociocultural approach as the most important basis in foreign language learning is conditioned by the desire to ensure the quality of modern education on the basis of maintaining its fundamentality and relevance to the actual as well as perspective needs of the individual and society.

Key words: socio-cultural approach, sociocultural competence, professionally oriented foreign language communication, socio-cultural communication means, audio-lingual method, dialogue of cultures, foreign language education, regional geographic information. 